\title{
New and emerging treatments for symptomatic tardive dyskinesia
}

\author{
This article was published in the following Dove Press journal: \\ Drug Design, Development and Therapy \\ 5 November 2013 \\ Number of times this article has been viewed
}

\author{
Abdul Qayyum Ranal-4 \\ Zishan M Chaudry ${ }^{5}$ \\ Pierre J Blanchet ${ }^{6}$ \\ 'Parkinson's Clinic of Eastern Toronto \\ and Movement Disorders Centre, \\ Toronto, ON, Canada; ${ }^{2}$ Scarborough \\ Memory Program, Toronto, ON, \\ Canada; ${ }^{3}$ Journal of Parkinsonism and \\ RLS, Toronto, ON, Canada; ${ }^{4}$ Bulletin \\ of World Parkinson's Program, \\ Toronto, ON, Canada; ${ }^{5} \mathrm{Saba}$ \\ University School of Medicine, \\ The Bottom, Saba, Dutch Caribbean; \\ ${ }^{6}$ Department of Stomatology, \\ University of Montreal, Montreal, \\ QC, Canada
}

\begin{abstract}
The aim of this review is to assess new, emerging, and experimental treatment options for tardive dyskinesia (TD). The methods to obtain relevant studies for review included a MEDLINE search and a review of studies in English, along with checking reference lists of articles. The leading explanatory models of TD development include dopamine receptor supersensitivity, GABA depletion, cholinergic deficiency, neurotoxicity, oxidative stress, changes in synaptic plasticity, and defective neuroadaptive signaling. As such, a wide range of treatment options are available. To provide a complete summary of choices we review atypical antipsychotics along with resveratrol, botulinum toxin, Ginkgo biloba, tetrabenazine, clonazepam, melatonin, essential fatty acids, zonisamide, levetiracetam, branched-chain amino acids, drug combinations, and invasive surgical treatments. There is currently no US Food and Drug Administration-approved treatment for TD; however, prudent use of atypical antipsychotics with routine monitoring remain the cornerstone of therapy, with experimental treatment options available for further management.
\end{abstract}

Keywords: tardive dyskinesia, first-generation antipsychotics, motor symptoms, schizophrenia, Parkinson's, atypical antipsychotics

\section{Introduction}

Tardive dyskinesia (TD) is an iatrogenic condition that results from the long-term use of dopaminergic antagonist medications, predominantly antipsychotics and metoclopramide, along with long-term use of dopamine (DA) agonists as treatment for Parkinson's disease. ${ }^{1,2}$ The term "tardive" refers to the delayed onset of the condition following drug initiation, while "dyskinesia" refers to the abnormal involuntary movements of the tongue, lips, face, trunk, and extremities characteristic of this condition. ${ }^{3}$ Movements may include tongue thrusting, lip smacking or pursing, grimacing and chewing movements, piano-playing finger movements, trunk and pelvic thrusting, flexion/extension of the ankles or toes, irregular respirations, and various vocalizations. $^{3}$ TD compounded with the effects of schizophrenia (SCZ) has been associated with $12.3 \%$ lower quality of life scores than in individuals without the side effects. ${ }^{4}$ A progressive decline in quality of life has also been perceived in patients with severe TD, with increasingly lower quality of life scores in the elderly, in whom the condition develops more rapidly and is more likely to be irreversible. ${ }^{4,5}$

Multiple risk factors of TD have been identified, including increased age, psychiatric diagnosis, female sex, a history of diabetes, organic brain damage, development of neurologic side effects, and the presence of negative symptoms related to SCZ. ${ }^{6}$ TD's prevalence in patients has been differentiated between the use of first-generation/ 
typical antipsychotics (FGAs/TAs) and second-generation/ atypical antipsychotics (SGAs/ATAs), with rates of $32.4 \%$ and $13.1 \%$, respectively, based on short-term studies and haloperidol as prime comparator. ${ }^{6}$ In a recent, prospective, 4-year study, ATA use reduced the cumulative risk for TD by one-third relative to TAs. ${ }^{7}$ Nonetheless, the complication remains prevalent and a proportion of one-third of patients chronically exposed to antipsychotic drugs still display TD, despite ATA prescription alone or in combination. ${ }^{7}$ The annual risk remains greater in older adults, particularly in those living with a dementing illness. ${ }^{8}$ Also, severe forms of TD may still develop with ATAs. ${ }^{9}$

The exact pathophysiological cause of TD is unknown and contested. The most prominent explanatory models include DA receptor (DA-R) supersensitivity, $\gamma$-aminobutyric acid (GABA) depletion, cholinergic deficiency, neurotoxicity and oxidative stress, changes in synaptic plasticity, and defective neuroadaptive signaling. ${ }^{10}$ Consequently, a wide range of treatment options have been suggested for further testing. To provide a complete summary of choices, this literary review assesses well-established, new and emerging, and experimental options. A summary of the evidence of treatment options for TD can be seen in Table 1.

\section{Development}

\section{DA-R supersensitivity}

Most antipsychotics antagonize the DA system. Most DA-R antagonists cause hypersensitization of DA-Rs, especially D2 type, via increased density in all DA pathways. ${ }^{11-13}$ DA-2 receptors (D2-Rs) exist in two distinct states: either high (D2 $2^{\text {high }}$ ) or low (D2 $\left.{ }^{\text {low }}\right)$ affinities for DA. Antipsychotic drugs, however, have identical affinities for both states. ${ }^{14}$ TAs are not as specific as ATAs and result in ubiquitous binding of D2-Rs. This mode of action disturbs DA levels in brain regions responsible for motor symptoms, resulting in motor dysfunction. ${ }^{15}$ Furthermore, TAs remain bound to D2-Rs and accumulate in brain tissue, leading to TD. ${ }^{16}$ These interactions cause increased density of D2-Rs, resulting in decreased efficacy of low-dose antipsychotics along with increased uptake of DA, especially after withdrawal of antipsychotics, resulting in TD.

In schizophrenic patients that have never been medicated with antipsychotics, there is an $8 \%-30 \%$ increase of D2-Rs in the frontal cortex and striatum. Additionally, animal models of SCZ (amphetamine sensitization and brain lesions) have shown D2-R density in the striatum to be normal, though $\mathrm{D} 2{ }^{\text {high }}$ receptors are elevated by $250 \%$ in the striatum. ${ }^{14}$

Hypersensitivity of DA-Rs is illustrated by many studies on rat models that exhibit spontaneous vacuous chewing movements (VCMs) with high-dose haloperidol. Under normal conditions, D2-Rs are inhibitory to the indirect striatopallidal pathway. Hypersensitivity of D2-Rs in this pathway will cause over-inhibition of the globus pallidus (GP) internus (GPi) and subthalamic nucleus, resulting in pathological involuntary movements. ${ }^{11}$ This is especially apparent in withdrawal of DA antagonists, in patients with D2-R supersensitivity, of which a common feature is involuntary dyskinetic movements, a finding attributed to excessive DA-binding in the extrapyramidal system owing to increased D2 receptor density and sensitivity from long-term use of most DA antagonists. ${ }^{12}$

Many studies have found continuous D2-R occupancy is not required for the treatment of SCZ, and such treatment can weaken antipsychotic efficacy and increase risk of TD by increasing supersensitivity of D2-Rs. ${ }^{17}$ Continuous treatment of haloperidol treatment, in one study on rats, resulted in the recovery of spontaneous motor activity that was otherwise suppressed by an antipsychotic, along with significant increase in VCMs. ${ }^{17}$ Intermittent occupancy of D2-Rs has been hypothesized to decrease negative effects of continuous dosing with a decreased likelihood to cause D2 upregulation, which would reduce tolerance development. ${ }^{17,18}$ As such, ATAs are associated with low or absent extrapyramidal symptoms (EPS), as they not only selectively bind to D2-Rs in the limbic system, but occasionally express low D2-R occupancy, allowing endogenous DA to access the receptor. 5-hydroxytryptamine (5-HT) plays an inhibitory role on DA-Rs, while 5-HT2C-R antagonism can lead to the release of DA in the mesostriatal system, especially when high doses are used. ${ }^{16,19,20}$

Neuroimaging and postmortem studies in humans have not yet conclusively supported increased striatal D2-R density in rodents. ${ }^{10,11}$

\section{GABAergic neuronal dysfunction}

Fast-spiking GABAergic interneurons in the striatum are normally responsible for maintaining a balance between the direct and indirect striatopallidal pathways. ${ }^{11}$ Conceivably, destruction of these during neuroleptic exposure can cause dyskinesia. ${ }^{10,11}$ Specifically, whereas an excess of GABA in the GP has been linked to Parkinsonism in animal models, a decrease of GABA in the GP and substantia nigra has been associated with hyperkinetic movements, including TD. ${ }^{12}$ Genetic associations between the GABA system and TD provide further proof linking GABAergic neuronal dysfunction to development of TD. ${ }^{13}$ Though treatment with GABA agonists may theoretically hold promise, it has shown mixed results thus far. ${ }^{12}$ 


\section{Cholinergic deficiency}

The cholinergic deficiency theory has been implicated in the development of TD due to increased VCMs in rat models treated with haloperidol. Grimm et al compared the number of cells containing acetylcholine in striatal and accumbal subregions with haloperidol exposure $(21 \mathrm{mg} / \mathrm{kg})$ or control vehicle (ie, sesame oil)-exposed rats. Rats treated with haloperidol showed a 1,400\% increase in VCM activity above controls followed by decreased counts of choline acetyltransferase (ChAT)-positive cells in the ventrolateral striatum and nucleus accumbens. ${ }^{21} \mathrm{~A}$ similar animal model study showed haloperidol-treated rats with low VCMs to have a $26 \%$ decrease in choline acetyltransferases, with a $29 \%$ $39 \%$ decrease in choline in high-VCM rats. ${ }^{22}$ Furthermore, a decrease in the density of ChAT-labeled cells was also seen: $26 \%$ in the haloperidol group and $37 \%$ in the high-VCM group..$^{22}$ The decrease of choline present in the two studies was in the ventrolateral striatum and nucleus accumbens; both areas have been associated with orofacial movements. ${ }^{22}$

\section{Neurotoxicity}

There is a natural increase in production of catecholamines to overcome DA-R blockade, which permits increased breakdown. ${ }^{11}$ This increased turnover of neurotransmitters (NTs) is suggested to cause oxidative stress in the brain, with free radical production causing lipid peroxidation, especially to striatal interneurons, resulting in a lack of inhibition: the foundation of neurotoxicity as a cause of TD. ${ }^{10-12}$ Haloperidol has been found to cause oxidative stress like other TAs, forming free radicals via the inhibition of complex 1 of the electron transport chain. ${ }^{12}$ Further literary support is provided by studies conducted on rats with TD using antioxidants such as alpha-phenyl- $N$-tert-butylnitrone. ${ }^{10,12}$ Extended use of neuroleptic treatment resulted in reduced nerve cell numbers in the substantia nigra of old rats with high VCM activity. ${ }^{23}$ Genetic studies have also supported the TD theory of neurotoxicity, with the alanine polymorphism of superoxide dismutase being protective against TD. ${ }^{12}$ Potential therapies for TD rooted in this theory have fundamental antioxidant function, including melatonin (MEL), Bauhinia forficata, and Ginkgo biloba.

\section{Synaptic plasticity}

Teo et $\mathrm{al}^{11}$ describe this phenomenon as an increase or decrease in synaptic transmission based on previous experience. There is some evidence of N-methyl-D-aspartate receptors (NMDA-Rs) and intracellular calcium implicated in this theory of neuronal plasticity giving rise to TD. ${ }^{11,13}$
This has been provided with some support through animal models where the use of an NMDA-R antagonist, memantine, resulted in a decrease in VCMs during haloperidol exposure. ${ }^{24}$ Such maladaptive plasticity is suggested to be implicated in hyperkinetic movement disorders, including TD.

\section{Defective neuroadaptive signaling}

Animal evidence suggests neurochemical changes induced by genetic deletion of Nur77, a transcriptional factor of the nuclear receptor family expressed in central dopaminergic pathways, and/or antagonism of the retinoid $\mathrm{X}$ receptor (RXR), also a nuclear receptor, might recapitulate some susceptibility processes observed in TD. Both Nur 77 and RXR are normally expressed in the caudate putamen (striatum) and are associated with motor function. ${ }^{25}$ Indeed, Nur 77 knockout mice display worsened haloperidol-induced VCMs compared to wild-type mice, and Nur77 expression is elevated in TDfree monkeys chronically exposed to haloperidol relative to animals with $\mathrm{TD}^{25,26}$ Interestingly, a single nucleotide polymorphism (rs2603751), located in the 3 '-untranslated regulatory region of the Nur 77 mRNA displayed a nominal association with the risk of developing TD and TD scores on the Abnormal Involuntary Movement Scale (AIMS), in a group of SCZ patients. ${ }^{27}$ Thus, agents that are able to increase Nur 77 expression, or that of its heterodimer partner, the retinoid $\mathrm{X}$ receptor, may benefit $\mathrm{TD}$. The polyunsaturated fatty acid docosahexaenoic acid, with agonist activity at the retinoid X receptor, has reduced VCMs in haloperidolexposed mice, while antagonism of RXR has been seen to increase EPS activity. ${ }^{25}$ This might provide a novel approach by which to prevent and/or palliate TD in humans.

\section{Management}

An empirical treatment algorithm, from Margolese et al, suggests several lines of intervention. ${ }^{28}$ A summary of the steps suggested by Margolese et a ${ }^{28}$ have been provided; gradual tapering of anticholinergic co-medications (as central anticholinergic co-medications have been seen to exacerbate and/or unmask TD) is the primary step followed by switching from the causative agent to ATA's (as they have been shown to reduce TD). Combination therapy with ATAs and/or tetrabenazine (TBZ) shoud be sought next, and, finally adding experimental therapy including donepezil/MEL/vitamin E/ vitamin B6/branched-chain amino acids (BCAAs) if each previous step does not provide relief. ${ }^{10,28}$ Experimental therapies are tried last as they have been shown to reduce TD; however, large-scale clinical trials are necessary to confirm results. ${ }^{28}$ Other interventions are discussed below. 


\section{Resveratrol}

Resveratrol is an antioxidative, anticancer, and antiinflammatory phytoalexin found in cranberries, peanuts, and grapes. ${ }^{29}$ In an animal model study by Busanello et al, rats were divided into four groups to test the effects of resveratrol when previously treated with reserpine, an antipsychotic drug that prompts EPS related to Parkinson's and orofacial dyskinesia. ${ }^{29}$ The specific goal was to determine the effects of resveratrol on VCMs and open-field locomotion largely due to oxidative damage..$^{29}$ The study established that the reserpine-only treatment group had a significant increase in VCMs, whereas co-treatment with reserpine-resveratrol resulted in a lower number of VCMs, thus demonstrating a protective effect against free radical-producing agents. ${ }^{29}$ There were no differences found amongst the groups when assessing effects on open-field locomotion. ${ }^{29}$

Another animal model study conducted by Busanello et al using resveratrol demonstrated a significant decrease in VCMs. Rats injected with fluphenazine, an antipsychotic, had significant increases in VCM activity; however, rats injected with both fluphenazine and resveratrol were protected from the increase in VCM activity. ${ }^{30}$ Again, resveratrol treatment did not play a role in open-field locomotion. Resveratrol has also been implicated in diminishing VCM activity in animal models other than rats, accounting for its use in Parkinson's and TD. ${ }^{30}$

\section{Botulinum toxin (Bt)}

Limited study has been done on the use of Bt in TD. Case studies on patients with involuntary tongue protrusion showed benefit with Bt injected in the genioglossal area. ${ }^{31}$

Additionally, a single-blind study was conducted that used Bt for the treatment of orofacial TD. ${ }^{32}$ Eight patients were treated with $\mathrm{Bt}$ for a period of 33 weeks with a gradual increase in dosage. The study found a nonsignificant decrease of orofacial TD symptoms measured by AIMS when the patient's antipsychotic treatment was allowed to fluctuate due to changes in their psychotic symptoms. However, when the antipsychotic dosage was kept constant, a significant decrease in AIMS scores was observed. ${ }^{32}$

There are limited and transient acute dystonic reactions for intralingual Bt therapy, with dysphagia and speech disturbances possibly developing with high doses. ${ }^{31}$

\section{G. biloba}

G. biloba was tested for its antioxidant potential as a treatment for TD in SCZ. In a double-blind study, a population of 157 patients were given either a special G. biloba extract
(EGb-761) or placebo over 12 weeks. The majority of patients in the G. biloba treatment group had an improvement in AIMS scores of greater than $30 \%$. Long-term benefits were also uncovered with G. biloba treatment, with no deterioration of the AIMS scores 12 weeks from the end of treatment. ${ }^{33}$

The direct scavenging, as well as indirect inhibition of free radicals via modulation of enzymes, are putative mechanisms of $G$. biloba function. ${ }^{33}$

\section{TBZ}

TBZ is an approved treatment in many countries for several hyperkinetic movement disorders, including Huntington's chorea. ${ }^{34,35}$ Its method of action involves vesicle monoamine transporter type 2 inhibition, normally responsible for monoamine uptake in presynaptic vesicles, causing NT depletion from the central nervous system.

Using MEDLINE as a search engine (from 1950 to February 2010), Guay uncovered ten retrospective trials on TD totaling 1,142 patients, of which $71 \%$ showed either marked improvement, excellent improvement, or complete improvement of their TD symptoms using TBZ. Sixteen open-label studies including 88 participants with TD were also discussed: $77 / 88$ patients responded positively. ${ }^{35}$ These results are promising for future approval of TBZ as a treatment option for TD.

Kenney et a $\mathrm{a}^{36}$ analyzed 448 patients treated chronically with TBZ for moderate or severe hyperkinetic movement disorders, including those with Huntington's chorea, TD, and dystonia. The study provided proof for long-term efficacy and safety of TBZ, with $70 \%$ of the study population relapsing with hyperkinetic involuntary movement when TBZ was removed.

Adverse drug reactions (ADRs) for TBZ are variable and suggested to be dose-dependent. ${ }^{36}$ Drowsiness (30\%) and Parkinsonism (27\%) are the most common ADRs; others include mood change and anxiety. ${ }^{35,36}$ Depression and an increased risk of suicide are the most extreme ADRs, with rare instances of hyperthermia and neuroleptic malignant syndrome also reported. ${ }^{35,36}$

\section{Clonazepam}

An indirect GABA agonist, clonazepam was evaluated in a double-bind, randomized, placebo-controlled study in patients being treated with neuroleptics. ${ }^{37}$ Nineteen patients between 18 and 65 years with mild to severe TD were given clonazepam for a span of 12 weeks; five of these patients were followed for up to 9 months to determine the longlasting effects of clonazepam. Clonazepam treatment showed 
a decrease in the dyskinesia score by $37.1 \%$ overall; the decrease in scores was statistically significant $(P<0.0003) .{ }^{37}$ In the long-term study of clonazepam, the five patients showed a decrease in the antidyskinetic actions of clonazepam after 5 to 8 months of continuous use. ${ }^{37}$ These patients were weaned off Clonazepam for 1 to 2 weeks, after which clonazepam was reinstituted; in this case, clonazepam again showed therapeutic effects on TD. ${ }^{37}$

\section{Clozapine}

Clozapine is a relatively safe ATA with GABA-A-R-modulating effects. ${ }^{38} \mathrm{~A}$ significant number of studies on clozapine suggest its beneficial use in TD due to its ability to decrease abnormal motor movements. ${ }^{39}$ Littrell and Magill studied SCZ patients with severe TD. Subjects were given clozapine therapy for at least 6 months, at which time they were analyzed for abnormal movements based on AIMS scores. Four of five patients showed ratings of 0 by the end of 4 months, with no further changes in scores during the fifth and sixth months; the AIMS score at the end of 4 months was 1, indicating a 94\% reduction of abnormal movements from baseline. ${ }^{39}$ Clozapine was shown to significantly decrease symptoms of preexisting TD; it also did not increase the symptoms of TD. ${ }^{39}$

In a related 5-year follow-up study investigating the therapeutic effects of clozapine on TD, similar results were seen. The original study administered clozapine to seven schizophrenic patients with severe TD aged between 17 and 55 years for 6 months; the mean clozapine dose was $392.86 \mathrm{mg} /$ day by the end of the study. ${ }^{40}$ After 6 months of treatment, a mean reduction of $52 \%$ was seen in the Extrapyramidal Symptom Rating Scale (ESRS) for dyskinesia. Additionally, one patient with dystonic movement showed complete remission, while another showed $50 \%$ reduction. ${ }^{40}$ In the 5-year follow-up, an $87.5 \%$ decrease in ESRS scores for TD was observed, up from $83 \%$ after 3 years. ${ }^{41}$ This could be attributed to the slight increase in dosage at 3 years $(400 \mathrm{mg} /$ day $)$ compared to at 5 years $(428 \mathrm{mg}$ / day). The Positive and Negative Symptom Scale (PANSS) ratings also showed a mean reduction of $50 \%$; reduction was seen mostly in positive symptoms ${ }^{41}$ One patient with dystonic movement had complete remission, with the remaining six showing mild or marginal dyskinetic symptoms. ${ }^{41}$ Various side effects were observed, including sialorrhea, excessive somnolence, blurred vision, and obstipation; however, all were moderate and were reduced during treatment. ${ }^{40}$

\section{MEL}

This hormone has shown antioxidant effects on dopaminergic neurons. MEL has been shown to prevent DA release in the central nervous system and the striatum of mammals, thus is perceived to possibly ameliorate TD. ${ }^{42}$ In a randomized, double-blind, placebo-controlled study performed by Castro et al, eleven patients showed no statistical significance in improvement when given $20 \mathrm{mg}$ /day of MEL, while two patients treated with MEL showed a significant improvement of more than $60 \%$ over the span of 12 weeks. ${ }^{42}$

In a related double-blind, placebo-controlled, crossover study with 22 patients given $10 \mathrm{mg}$ /day of MEL over the span of 6 weeks, patients showed a decrease in the AIMS score for both the MEL and the placebo treatments. ${ }^{43}$ The decrease for MEL was by approximately 2.45 points and for the placebo it was by 0.77 points on AIMS; seven patients showed clinical improvement during MEL treatment and, overall, improvement by $30 \%$ or more was seen in $9 / 22$ patients. ${ }^{43}$ It should be noted that clinical significance outcome in TD treatment is usually defined by a reduction greater than 3 points in the AIMS score, and a decrease by 2.45 is not considered to be clinically significant. ${ }^{44}$ Despite the aforementioned rule, the authors $^{43}$ concluded that MEL is effective in the treatment of TD due to the relatively significant visible improvement (by $30 \%$ ) in patients. ${ }^{44}$

\section{Essential fatty acids (EFAs) (omega-3)}

Omega-3 fatty acids are essential as they contain eicosapentaenoic and docosahexaenoic acids, both necessary for human health and unable to be produced by the body. ${ }^{45}$ EFAs play an important role in the function of NT receptors and are believed to encourage neurotropic factor and improve neurotransmission, as well as have neuroprotective and antidepressant properties. ${ }^{45}$ Individuals with TD have been shown to have lower levels of EFAs compared to psychiatric controls without TD. ${ }^{46}$ Furthermore, omega- 3 fatty acids promote neuronal growth; on this basis, omega-3 fatty acids are hypothesized to play a role in the treatment of TD. In a recent animal model study, Nur77 gene-deficient mice were used along with mice that were given haloperidol in order to induce VCM activity. ${ }^{25}$ Coadministration of docosahexaenoic acid, at $100 \mathrm{mg} / \mathrm{kg} /$ day over a span of 8 days, reduced haloperidol VCMs in wild-type mice with Nur77 $(+/+)(P<0.05) .{ }^{25}$ Docosahexaenoic acid did not show reduction of VCMs in mice that were Nur77 deficient. ${ }^{25}$ Although EFAs are classified as experimental therapy there is significant potential for EFAs in the management of TD.

\section{Zonisamide}

Zonisamide is a sulphonamide antiepileptic drug often used to treat partial-onset, myoclonic, or generalized 
Table I Summary of the evidence for treatment options of tardive dyskinesia

\begin{tabular}{|c|c|c|c|c|}
\hline Authors & Study design & Regimen & Results & Adverse effects \\
\hline $\begin{array}{l}\text { Mentzel } \\
\text { et al }{ }^{6}\end{array}$ & $\begin{array}{l}\text { PubMed and Embase } \\
\text { databases were searched } \\
\text { on May } 25,201 \text { I for English- } \\
\text { language articles. }\end{array}$ & $\begin{array}{l}\text { Search terms: "deep brain } \\
\text { stimulation" AND "tardive". } \\
\text { I7 studies involving } 50 \text { patients } \\
\text { with TD who underwent } \\
\text { DBS were included. }\end{array}$ & $\begin{array}{l}77.5 \% \text { improvement was seen } \\
\text { on the Burke-Fahn-Marsden } \\
\text { Dystonia Rating Scale. }\end{array}$ & $\begin{array}{l}\text { I patient experienced } \\
\text { increase in depression } \\
\text { and another experienced } \\
\text { increased psychosis. }\end{array}$ \\
\hline $\begin{array}{l}\text { Woods } \\
\text { et } \mathrm{al}^{7}\end{array}$ & $\begin{array}{l}\text { Cohort study of TD incidence. } \\
\mathrm{N}=35 \text { TD-free outpatients. }\end{array}$ & $\begin{array}{l}\text { AIMS scores were taken } \\
\text { twice at every visit along } \\
\text { with Glazer-Morgenstern } \\
\text { criteria for dyskinesia. }\end{array}$ & $\begin{array}{l}\text { TD incidence with ATAs alone } \\
\text { was similar to that of } \\
\text { conventional therapy; the incident } \\
\text { ratio was approximately } 0.68 \text {. }\end{array}$ & $\mathrm{N} / \mathrm{A}$ \\
\hline $\begin{array}{l}\text { Ragheb and } \\
\text { Goldberg }{ }^{10}\end{array}$ & $\begin{array}{l}\text { Double-blind dose-response } \\
\text { study; } \mathrm{N}=23 \text { schizophrenic } \\
\text { patients with and without TD. }\end{array}$ & $\begin{array}{l}100 \mathrm{mg}, 300 \mathrm{mg} \text {, and } 600 \mathrm{mg} \\
\text { clozapine. }\end{array}$ & $\begin{array}{l}600 \mathrm{mg} \text { and } 300 \mathrm{mg} \text { were } \\
\text { significantly lower than baseline } \\
\text { values; } 100 \mathrm{mg} \text { was not. } 100 \mathrm{mg} \\
\text { dose showed worsening ADR } \\
\text { scores. Switching from } 600 \mathrm{mg} \\
\text { to } 300 \text { or } 100 \mathrm{mg} \text { resulted in } \\
\text { loss of ameliorative effect. }\end{array}$ & $\mathrm{N} / \mathrm{A}$ \\
\hline $\begin{array}{l}\text { Grimm } \\
\text { et } \mathrm{al}^{21}\end{array}$ & Female rats; 3 months old. & $\begin{array}{l}\text { Haloperidol decanoate } \\
(21 \mathrm{mg} / \mathrm{kg}) \text { every } 3 \text { weeks } \\
\text { for } 24 \text { weeks. Sesame seed } \\
\text { oil }(21 \mathrm{mg} / \mathrm{kg} \text { ) every } 3 \text { weeks } \\
\text { for } 24 \text { weeks. }\end{array}$ & $\begin{array}{l}\text { Haloperidol-treated animals: } \\
\text { elevated VCM activity, } \\
\text { approximately } 140 \% \text { above } \\
\text { controls. Decreased ChAT } \\
\text { cells in ventrolateral striatum } \\
\text { and nucleus accumbens. }\end{array}$ & N/A \\
\hline $\begin{array}{l}\text { Kelley and } \\
\text { Roberts }^{22}\end{array}$ & $\mathrm{~N}=50$ albino rats. & $\begin{array}{l}2.5 \mathrm{mg} \text { haloperidol/ } / 00 \mathrm{~mL} \\
\text { of water. }\end{array}$ & $\begin{array}{l}\text { Haloperidol-treated rats } \\
\text { had } 26 \% \text { decrease in ChAT } \\
\text { immunoreactive neurons, with } \\
29 \%-39 \% \text { decrease of choline } \\
\text { in high-VCM rats. }\end{array}$ & $\mathrm{N} / \mathrm{A}$ \\
\hline $\begin{array}{l}\text { Pappa } \\
\text { et } \mathrm{al}^{24}\end{array}$ & $\begin{array}{l}\text { Double-blind, placebo- } \\
\text { controlled crossover design. } \\
\mathrm{N}=22 \text { patients with TD. }\end{array}$ & $\begin{array}{l}100 \mathrm{mg} \text { amantadine or } \\
\text { placebo. }\end{array}$ & $\begin{array}{l}\text { Total reduced score from } \\
12.5 \text { to } 10.5 \text { from amantadine } \\
\text { treatment for orofacial } \\
\text { dyskinetic symptoms. Average } \\
\text { total AIMS reduction was } \\
21.81 \% \text {. No reduction was } \\
\text { noted in the placebo treatment. }\end{array}$ & $\begin{array}{l}\text { No adverse events or side } \\
\text { effects were noted. }\end{array}$ \\
\hline Ethier et $\mathrm{a}^{25}$ & $\begin{array}{l}\text { Young adult wild-type male } \\
\text { mice and Nur77 knockout } \\
\text { (Nur77 [-I-]) mice. }\end{array}$ & $\begin{array}{l}\text { DHA (100 mg/kg/day), } \\
\text { HX53I ( } 20 \mathrm{mg} / \mathrm{kg} / \text { day), } \\
\text { haloperidol alone }(\mathrm{I} \mathrm{mg} / \mathrm{kg}) \text {, } \\
\text { haloperidol + DHA. }\end{array}$ & $\begin{array}{l}\text { Nur77 (-I-) mice had high VCM } \\
\text { activity along with wild-type } \\
\text { mice that were given HX53I. } \\
\text { DHA alone had no effect on wild } \\
\text { type mice or Nur77 (-l-) mice. } \\
\text { Coadministration of DHA and } \\
\text { haloperidol reduced VCMs in } \\
\text { wild-type mice. }\end{array}$ & $\mathrm{N} / \mathrm{A}$ \\
\hline $\begin{array}{l}\text { Busanello } \\
\text { et } \mathrm{al}^{29}\end{array}$ & $\begin{array}{l}\text { Albino Swiss mice weighing } \\
27-32 \mathrm{~g} .\end{array}$ & $\begin{array}{l}\text { Reserpine }(1 \mathrm{mg} / \mathrm{kg}) \text { and } \\
\text { resveratrol }(5 \mathrm{mg} / \mathrm{kg}) \text {. }\end{array}$ & $\begin{array}{l}\text { Reserpine increased VCM activity. } \\
\text { Reserpine-resveratrol co-treatment } \\
\text { showed lower VCM. No change in } \\
\text { locomotors or exploratory activity } \\
\text { was seen. Resveratrol alone did not } \\
\text { modify VCM. }\end{array}$ & N/A \\
\hline $\begin{array}{l}\text { Busanello } \\
\text { et } \mathrm{al}^{30}\end{array}$ & Rats weighing $270-320 \mathrm{~g}$. & $\begin{array}{l}\text { Fluphenazine enante } \\
(25 \mathrm{mg} / \mathrm{kg}) \text { and resveratrol } \\
(1 \mathrm{mg} / \mathrm{kg}) \text { for } 2 \mathrm{I} \text { days. }\end{array}$ & $\begin{array}{l}\text { Fluphenazine increased VCM } \\
\text { prevalence. Resveratrol reduced } \\
\text { prevalence to } 30 \%(P=0.07) \text {, but } \\
\text { not when administered alone. }\end{array}$ & $\mathrm{N} / \mathrm{A}$ \\
\hline $\begin{array}{l}\text { Slotema } \\
\text { et } \mathrm{al}^{32}\end{array}$ & $\begin{array}{l}\text { Single-blind study. } N=12 \\
\text { patients with orofacial TD. }\end{array}$ & $\begin{array}{l}\text { Botulinum toxin was injected } \\
\text { at } 40 \mathrm{mg} \text {. The dosage could be } \\
\text { increased to } 60 \mathrm{Mu} \text { or } 80 \mathrm{Mu} \text {. }\end{array}$ & $\begin{array}{l}\text { Patients who changed } \\
\text { antipsychotic medication showed } \\
\text { no change. Patients who did } \\
\text { not change their antipsychotic } \\
\text { medication showed a significant } \\
\text { reduction }(P=0.035)\end{array}$ & $\mathrm{N} / \mathrm{A}$ \\
\hline
\end{tabular}


Table I (Continued)

\begin{tabular}{|c|c|c|c|c|}
\hline Authors & Study design & Regimen & Results & Adverse effects \\
\hline $\begin{array}{l}\text { Zhang } \\
\text { et } \mathrm{al}^{33}\end{array}$ & $\begin{array}{l}\text { Double-blind study. } \\
\mathrm{N}=157 \text { patients with TD. }\end{array}$ & $\begin{array}{l}\text { Special GB extract (Egb-76I) } \\
\text { or placebo. }\end{array}$ & $\begin{array}{l}\text { Improvement in AIMS score } \\
\text { of greater than } 30 \% \text {; no } \\
\text { deterioration of AIMS score } \\
\text { was seen after } 12 \text { weeks. }\end{array}$ & $\begin{array}{l}\text { No adverse side effects } \\
\text { were noted. }\end{array}$ \\
\hline Howland ${ }^{34}$ & $\begin{array}{l}\text { Literary review of causes } \\
\text { and therapies of TD. }\end{array}$ & $\begin{array}{l}\text { Articles on antipsychotic } \\
\text { drug-induced motor syndromes, } \\
\text { ATA drugs, DA-depleting drugs, } \\
\text { DA-modulating drugs were } \\
\text { searched. }\end{array}$ & $\begin{array}{l}\text { Second-generation antipsychotic } \\
\text { drugs should be used. DA- } \\
\text { depleting drugs are effective } \\
\text { along with DA-modulating drugs. }\end{array}$ & $\begin{array}{l}\text { DA-depleting drugs have } \\
\text { shown severe side effects } \\
\text { such as depression, } \\
\text { Parkinsonian effects, } \\
\text { akathisia and orthostatic } \\
\text { hypotension. }\end{array}$ \\
\hline Guay $^{35}$ & $\begin{array}{l}\text { Reviews the chemistry, } \\
\text { pharmacology, } \\
\text { pharmacokinetics, } \\
\text { therapeutic use, tolerability, } \\
\text { drug interaction potential, } \\
\text { and dosing and administration } \\
\text { of TBZ. }\end{array}$ & $\begin{array}{l}\text { MEDLINE was searched } \\
\text { (I } 950 \text { to February 20I0) } \\
\text { for English-language articles } \\
\text { investigating any aspect } \\
\text { of TBZ. Search terms } \\
\text { included “tetrabenazine," } \\
\text { "Ro I-9569," "Nitoman }{ }^{\circledR}, \\
\text { "benzoquinolizines," and } \\
\text { "reserpine." }\end{array}$ & $\begin{array}{l}\text { Clinical studies suggest that } \\
\text { TBZ may have therapeutic } \\
\text { applications in a wide range } \\
\text { of hyperkinetic movement } \\
\text { disorders. }\end{array}$ & $\begin{array}{l}\text { TBZ has been } \\
\text { associated with numerous } \\
\text { adverse effects, some of } \\
\text { them serious and } \\
\text { potentially fatal; these } \\
\text { include Parkinsonism, } \\
\text { other extrapyramidal } \\
\text { symptoms (particularly } \\
\text { akathisia), depression and } \\
\text { suicidality, neuroleptic } \\
\text { malignant syndrome, and } \\
\text { sedation. }\end{array}$ \\
\hline $\begin{array}{l}\text { Kenney } \\
\text { et } \mathrm{al}^{36}\end{array}$ & $\begin{array}{l}\text { Retrospective chart review } \\
\text { from 1997-2004. } N=448 \\
\text { patients with hyperkinesia, } \\
\text { TD, dystonia, chorea, and } \\
\text { myoclonus. }\end{array}$ & TBZ. & $\begin{array}{l}\text { Majority of patients improved } \\
\text { with TBZ treatment. }\end{array}$ & $\begin{array}{l}\text { Adverse side effects } \\
\text { included drowsiness } \\
\text { (25\%), Parkinsonism } \\
\text { (15.4\%), depression (7.6\%) } \\
\text { and akathisia (7.6\%). }\end{array}$ \\
\hline $\begin{array}{l}\text { Thaker } \\
\text { et } \mathrm{al}^{37}\end{array}$ & $\begin{array}{l}\text { Double-blind, placebo- } \\
\text { controlled, randomized } \\
\text { crossover trial. } \mathrm{N}=19 \text { (mean } \\
\text { age } 39.14 \text { years) chronically ill } \\
\text { with TD were treated with } \\
\text { neuroleptics. }\end{array}$ & $\begin{array}{l}\text { Clonazepam: I I patients } \\
\text { were given } 4-4.5 \mathrm{mg} / \mathrm{day} \text {, } \\
6 \text { were given } 3 \mathrm{mg} / \text { day, } \\
\text { and } 2 \text { were given } 2 \mathrm{mg} / \text { day. }\end{array}$ & $\begin{array}{l}\text { Dyskinesia was reduced by } 37.1 \% \\
\text { overall. Antidyskinetic effect was } \\
\text { higher ( } 41.5 \%) \text { in patients with } \\
\text { dystonic symptoms than those } \\
\text { with choreoathetoid symptoms } \\
\text { ( } 26.5 \%) \text {. Long-term effect of } \\
\text { clonazepam in } 5 \text { patients showed } \\
\text { decrease in dyskinetic symptoms. }\end{array}$ & $\begin{array}{l}3 \text { patients showed with } \\
\text { ataxia, and one with } \\
\text { nausea. I5-20 mmHg } \\
\text { drop in diastolic and } \\
\text { systolic BP was measured } \\
\text { in one patient (reduction } \\
\text { of dosage cured this). } \\
\text { Increase in anxiety in one } \\
\text { patient and dyskinetic } \\
\text { symptoms in another } \\
\text { were seen during placebo } \\
\text { administration after } \\
\text { clonazepam administration. } \\
\text { Long-term treatment } \\
\text { with clonazepam } \\
\text { showed disappearance of } \\
\text { antidyskinetic effect after } \\
5 \text {-8 months. Withdrawal } \\
\text { and readministration } \\
\text { after } 2 \text { weeks cured this. }\end{array}$ \\
\hline Howland ${ }^{38}$ & $\begin{array}{l}\text { Literary review of drug } \\
\text { therapies for TD. }\end{array}$ & $\begin{array}{l}\text { Articles on essential fatty } \\
\text { acids, BCAAs, GABA- } \\
\text { modulating drugs, } \\
\text { cardiovascular drugs, } \\
\text { antioxidant drugs were } \\
\text { searched. }\end{array}$ & $\begin{array}{l}\text { BCAA and GABA-modulating } \\
\text { drugs are safe and provide } \\
\text { some benefit for TD. Essential } \\
\text { fatty acids have not been shown } \\
\text { to be effective. Antioxidant } \\
\text { therapies could be used } \\
\text { together. }\end{array}$ & $N / A$ \\
\hline $\begin{array}{l}\text { Littrell and } \\
\text { Magill }^{39}\end{array}$ & $\mathrm{~N}=12$ with TD. & 6 months of clozapine. & $\begin{array}{l}\text { AIMS scores for } 4 \text { patients } \\
\text { were } 0 \text {, which was maintained } \\
\text { for } 12 \text { months. I patient } \\
\text { received a score of } 2 .\end{array}$ & N/A \\
\hline
\end{tabular}


Table I (Continued)

\begin{tabular}{|c|c|c|c|c|}
\hline Authors & Study design & Regimen & Results & Adverse effects \\
\hline $\begin{array}{l}\text { Bassitt } \\
\text { and Louzã } \\
\text { Neto }^{40}\end{array}$ & $\begin{array}{l}\mathrm{N}=7 \text { schizophrenic } \\
\text { patients with severe TD. }\end{array}$ & 392.86 mg/day of clozapine. & $\begin{array}{l}\text { Mean reduction of } 52 \% \text { in ESRS } \\
\text { scores after } 6 \text { months. One } \\
\text { patient was completely remitted } \\
\text { of dystonic movement while } \\
\text { another showed } 50 \% \text { reduction. }\end{array}$ & $\begin{array}{l}\text { Sialorrhea, excessive } \\
\text { somnolence, blurred } \\
\text { vision, and obstipation. }\end{array}$ \\
\hline $\begin{array}{l}\text { Louzã and } \\
\text { Bassitt }^{4 !}\end{array}$ & $\begin{array}{l}\text { 5-year follow-up study of } \\
7 \text { schizophrenic patients. }\end{array}$ & $\begin{array}{l}\text { Dosage of clozapine after } \\
3 \text { years was } 400 \mathrm{mg} / \text { day; } \\
\text { after } 5 \text { years it was } \\
428 \mathrm{mg} / \text { day. }\end{array}$ & $\begin{array}{l}87.5 \% \text { decrease in ESRS scores } \\
\text { for TD was seen after } 5 \text { years } \\
\text { and } 83 \% \text { after } 3 \text { years. }\end{array}$ & $\begin{array}{l}\text { No adverse side effects } \\
\text { were noted. }\end{array}$ \\
\hline $\begin{array}{l}\text { Castro } \\
\text { et } \mathrm{al}^{42}\end{array}$ & $\begin{array}{l}\text { Randomized, double blind, } \\
\text { placebo-controlled design. } \\
\mathrm{N}=7 \text { patients with TD. }\end{array}$ & 20 mg/day of melatonin. & $\begin{array}{l}2 \text { patients showed more } \\
\text { than } 60 \% \text { improvement. No } \\
\text { differences were noted in the } \\
\text { other } 5 \text { patients. }\end{array}$ & N/A \\
\hline $\begin{array}{l}\text { Shamir } \\
\text { et } \mathrm{al}^{43}\end{array}$ & $\begin{array}{l}\text { Double-blind, placebo- } \\
\text { controlled crossover } \\
\text { study; } \mathrm{N}=22 \text { patients with } \\
\text { schizophrenia and TD. }\end{array}$ & $\begin{array}{l}10 \mathrm{mg} / \text { day melatonin for } \\
6 \text { weeks. }\end{array}$ & $\begin{array}{l}2.45 \text { decrease in AIMS score for } \\
\text { melatonin and } 0.77 \text { for placebo } \\
\text { treatment }(P<0.00 \text { I). }\end{array}$ & $\begin{array}{l}\text { No adverse events or } \\
\text { side effects were noted. }\end{array}$ \\
\hline $\begin{array}{l}\text { Nelson } \\
\text { et } \mathrm{al}^{44}\end{array}$ & $\begin{array}{l}\text { Literature found through } \\
\text { MEDLINE (I966 to } \\
\text { September 2002) and } \\
\text { PsycINFO (1967 to } \\
\text { September 2002). }\end{array}$ & $\begin{array}{l}\text { Review articles, case reports/ } \\
\text { series, and animal and human } \\
\text { studies were taken into } \\
\text { consideration. }\end{array}$ & $\begin{array}{l}\text { Animal studies and several } \\
\text { human case series describe an } \\
\text { association between melatonin } \\
\text { and TD. There are inadequate } \\
\text { data at the present time to } \\
\text { support the use of melatonin } \\
\text { in patients with TD. }\end{array}$ & $\mathrm{N} / \mathrm{A}$ \\
\hline $\begin{array}{l}\text { Iwata } \\
\text { et } \mathrm{al}^{47}\end{array}$ & $\begin{array}{l}\mathrm{N}=\text { II patients with } \\
\text { schizophrenia, bipolar } \\
\text { affective disorder, } \\
\text { schizoaffective disorder, } \\
\text { mental retardation with TD. }\end{array}$ & $50-100$ mg/day of zonisamide. & $\begin{array}{l}\text { AIMS total score decreased } \\
\text { from } 24.1 \text { to } 19.5 \text { with } 36 \% \text { of } \\
\text { subjects showing } 20 \% \text { or more } \\
\text { decrease in AIMS score. }\end{array}$ & Well tolerated. \\
\hline $\begin{array}{l}\text { Woods } \\
\text { et } \mathrm{al}^{50}\end{array}$ & $\begin{array}{l}\text { Double-blind, placebo- } \\
\text { controlled, randomized } \\
\text { study. } \mathrm{N}=50 \text { patients } \\
\text { with TD. }\end{array}$ & $\begin{array}{l}\text { Levetiracetam } 500 \mathrm{mg} / \text { day } \\
\text { to } 3,000 \mathrm{mg} / \text { day or placebo } \\
\text { for } 12 \text { weeks. }\end{array}$ & $\begin{array}{l}\text { AIMS total score decreased } \\
43.5 \% \text { from baseline score } \\
\text { compared to } 18.7 \% \text { for placebo. }\end{array}$ & $\begin{array}{l}\text { Emergent ataxia, } \\
\text { impaired coordination. }\end{array}$ \\
\hline Konitsiotis ${ }^{51}$ & $\begin{array}{l}\text { Open-label study. } \mathrm{N}=8 \\
\text { with psychosis and } \\
\text { antipsychotic-induced TD. }\end{array}$ & $\begin{array}{l}\text { Levetiracetam at } 1,000 \mathrm{mg} \text {, } \\
\text { twice a day. }\end{array}$ & $\begin{array}{l}\text { AIMS score significantly reduced } \\
\text { from I } 5.8 \text { to } 8.3 \text { and a total } \\
\text { mean reduction of } 44 \% \text { was seen. }\end{array}$ & $\begin{array}{l}\text { One patient presented } \\
\text { with somnolence during } \\
\text { treatment. }\end{array}$ \\
\hline $\begin{array}{l}\text { Emsley } \\
\text { et } \mathrm{al}^{52}\end{array}$ & $\begin{array}{l}\text { Single-blind, randomized } \\
\text { trial. } \mathrm{N}=45 \text { patients with TD. }\end{array}$ & $\begin{array}{l}400 \mathrm{mg} \text { of quetiapine was given } \\
\text { per day. haloperidol was given } \\
\text { at } 10 \mathrm{mg} \text { per day. }\end{array}$ & $\begin{array}{l}\text { Furthermore, a response rate } \\
\text { (symptom reduction) of greater } \\
\text { than } 50 \% \text { was seen in quetiapine } \\
\text { than haloperidol. }\end{array}$ & $\begin{array}{l}\text { No changes were } \\
\text { recorded. }\end{array}$ \\
\hline $\begin{array}{l}\text { Richardson } \\
\text { et } \mathrm{al}^{53}\end{array}$ & $\begin{array}{l}\text { Double-blind placebo study. } \\
\text { All males from a psychiatric } \\
\text { center with long-standing TD. }\end{array}$ & $\begin{array}{l}\text { Placebo. Low ( } 56 \mathrm{mg} / \mathrm{kg}) \text {, } \\
\text { medium (I } 67 \mathrm{mg} / \mathrm{kg}) \text {, or } \\
\text { high }(222 \mathrm{mg} / \mathrm{kg}) \text { BCAA. }\end{array}$ & $\begin{array}{l}\text { Amino acid group showed a } \\
\text { decrease of } 36.5 \% \text { in TD and } \\
\text { placebo showed a } 2.4 \% \\
\text { increase in TD movements. }\end{array}$ & $\mathrm{N} / \mathrm{A}$ \\
\hline $\begin{array}{l}\text { Richardson } \\
\text { et } \text { al }^{54}\end{array}$ & $\begin{array}{l}\mathrm{N}=6 \text { children and } \\
\text { adolescents with TD } \\
\text { symptoms. }\end{array}$ & $\begin{array}{l}222 \mathrm{mg} / \mathrm{kg} \text { BCAA in } \\
148 \mathrm{~mL} \text { water, } 3 \text { times a day. }\end{array}$ & $\begin{array}{l}\text { TD symptoms decreased in } \\
5 \text { of } 6 \text { patients from } 40 \% \text { to } 65 \% \text {. }\end{array}$ & $\begin{array}{l}\text { I patient showed } \\
\text { worsening of TD } \\
\text { symptoms over the } \\
\text { 2-week trial. }\end{array}$ \\
\hline $\begin{array}{l}\text { Kimiagar } \\
\text { et } \mathrm{al}^{55}\end{array}$ & $\begin{array}{l}\mathrm{N}=6 \text { patients with } \\
\text { buccolingual dyskinesia. }\end{array}$ & $\begin{array}{l}\text { Combination of TBZ } \\
(50 \mathrm{mg}) \text {, clonazepam ( } \mathrm{l} \mathrm{mg}) \text {, } \\
\text { and clozapine ( } 25 \mathrm{mg}) \text {. }\end{array}$ & $\begin{array}{l}\text { All patients were free of TD } \\
\text { symptoms within } 4 \text { weeks. }\end{array}$ & $\mathrm{N} / \mathrm{A}$ \\
\hline $\begin{array}{l}\text { Thobois } \\
\text { et } \mathrm{al}^{56}\end{array}$ & $\begin{array}{l}3 \text { case studies of surgical } \\
\text { lesion in the striatum. }\end{array}$ & Pallidotomy or thalamotomy. & $\begin{array}{l}\text { Resulted in } 78 \% \text { decrease in } \\
\text { AIMS score. }\end{array}$ & $\begin{array}{l}\text { No major psychiatric } \\
\text { side effects. }\end{array}$ \\
\hline $\begin{array}{l}\text { Welter } \\
\text { et } \mathrm{al}^{57}\end{array}$ & $\begin{array}{l}\mathrm{N}=10 \text { patients with } \\
\text { refractory neuroleptic- } \\
\text { induced TD. }\end{array}$ & $\begin{array}{l}\text { DBS of the globus pallidus } \\
\text { internus. }\end{array}$ & $\begin{array}{l}\text { Average improvement of } 56 \% \\
\text { and } 61 \% \text { on AIMS and ESRS } \\
\text { scores, respectively. }\end{array}$ & $\mathrm{N} / \mathrm{A}$ \\
\hline
\end{tabular}

Abbreviations: ADR, adverse drug reaction; AIMS, Abnormal Involuntary Movement Scale; ATA, atypical antipsychotics; BCAA, branched-chain amino acid; BP, blood pressure; DA, dopamine; DBS, deep brain stimulation; DHA, docosahexaenoic acid; ESRS, Extrapyramidal Symptom Rating Scale; GABA, $\gamma$-aminobutyric acid; GB, Ginkgo biloba; HX53I, 4-(5H-2,3-(2,5-Dimethyl-2, 5-hexano)-5-methyl-8-nitrodibenzo-[b,e][I,4]diazepin-I I-yl)benzoic acid; N/A, not applicable; TBZ, tetrabenazine; TD, tardive dyskinesia; VCM, vacuous chewing movement. 
tonic-clonic seizures along with infantile spasms. ${ }^{47}$ This drug has been seen to decrease the formation of 8-hydroxy$2^{\prime}$-deoxyguanosine, a marker of oxidative damage of DNA. ${ }^{47}$ It is also implicated in enhancing GABA release via allosteric action on GABA receptors. ${ }^{47,48}$ Iwata et al tested the efficacy, safety, and tolerability of zonisamide in eleven patients with TD. The 4-week open-label study included patients with SCZ, bipolar affective disorder, and mental retardation; patients were either taking or had taken antipsychotics for approximately $39.4 \pm 18.1 \mathrm{SD}$ years and were being treated with a final dose of $81.2 \mathrm{mg} /$ day $\pm 25.2 \mathrm{mg} /$ day. The AIMS total score decreased from 24.1 to 19.5 , with a $20 \%$ or more decrease in the AIMS score for $36.4 \%$ of subjects, identified as significant benefits to patients. ${ }^{47}$

\section{Levetiracetam (LEV)}

The proposed method of action of LEV, a levorotary stereoisomer of piracetam, is binding to synaptic vesicle protein $2 \mathrm{~A}$ and reducing NT release during trains of high-frequency activity. ${ }^{49}$

Woods et al tested the efficacy of LEV in a placebocontrolled, randomized trial of 50 patients with TD, with patients receiving either placebo or LEV (up to 3,000 mg/day over the 3-month study period). The LEV treatment group achieved improvements in their AIMS scores of $43.5 \%$ on average compared with $18.7 \%$ with placebo. Furthermore, following the double-blind phase, participants in the placebo group were given the opportunity to enroll into LEV treatment; these patients had a total decrease of $39 \%$ in AIMS scores from baseline. ${ }^{50}$

Similarly, declines of $44 \%$ in AIMS scores have been reported in an open-label study using LEV. ${ }^{51}$ This team also measured efficacy of LEV using the Unified Dyskinesia Scale (UDS) and the Clinical Global Impressions (CGI) scale, finding a $44 \%$ and $26 \%$ decrease on average, respectively.

These studies are often limited by their open-label design, small number of participants, and short duration. The most common ADR from LEV treatment is somnolence, with some incidence of irritability and aggression, which should be closely monitored, particularly in psychiatric patients. Increased risk of suicide is a rare yet critical finding as well..$^{50,51}$

\section{Quetiapine}

An ATA with D2-R and 5-HT-2AR blocking effects, ${ }^{34}$ quetiapine is associated with low striatal D2-R binding, rapid release from D2-Rs, and a lack of antimuscarinic activity, making it a potentially viable treatment plan for
TD. Quetiapine and clozapine dissociate from D2-Rs one hundred times faster than haloperidol, with the rapid release accounting for the low D2-R occupancy shown by quetiapine and clozapine. Rapid release from D2-Rs also implies that accumulation of antipsychotics does not occur in brain tissue, which reduces the risk of TD ${ }^{16}$ Furthermore, ATAs show limbic selective D2/D3-R blockade, resulting in decreased EPS, as opposed to TAs that are not selective and show increased binding in the striatum. ${ }^{19} \mathrm{~A}$ single-blind, randomized trial study by Emsley et al using haloperidol and quetiapine was conducted to determine the efficacy of quetiapine compared to haloperidol in the treatment of SCZ patients with TD. ${ }^{52}$ Forty-five subjects, males and females between the ages of 18 and 65 years, were sorted into two treatment groups in which, after the titration period, they received $400 \mathrm{mg}$ /day of quetiapine or $10 \mathrm{mg}$ /day of haloperidol. ${ }^{52}$ Both treatments showed improved TD activity, with patients in the quetiapine treatment group performing significantly better than those in the haloperidol group: $55 \%$ of the patients reached greater than $50 \%$ reduction on the CGI scale. Furthermore, quetiapine treatment subjects showed fewer EPSs and were also prescribed fewer anticholinergic medications. ${ }^{52}$ Though TD symptoms did not worsen in either treatment group, ten patients in the quetiapine treatment group and eight in the haloperidol treatment group withdrew due to an increase in psychosis, possibly as a result of the low dosage administered. ${ }^{52}$

\section{BCAAs}

Dyskinetic movements seen in patients with phenylketonuria led to the suspicion of amino acid (AA) involvement in the pathogenesis of TD. ${ }^{53}$ Confirmed with oral challenge and protein meal tests, a high concentration of BCAAs (leucine, isoleucine, valine) causes an increased ratio to aromatic AAs, suppressing synthesis of NTs including DA, 5-HT, and norepinephrine. ${ }^{38,53}$ In a study designed to test the efficacy of BCAA treatment for TD in men, 36 patients with a mean age of 44.6 years with a diagnosis of SCZ, schizoaffective disorder, bipolar disorder, substance-induced psychosis, or unspecified psychosis with neuroleptic-induced TD were given either placebo or high doses $(222 \mathrm{mg} / \mathrm{kg})$ of BCAAs three times a day for 3 weeks, with TD movements rated weekly. Compared to their baseline symptoms, there was an average decrease of $36.5 \%$ of TD movements on the Simpson Abbreviated Dyskinesia Scale (SADS) in the group receiving BCAA therapy, compared to an average increase of $3.4 \%$ in the placebo group, signifying great efficacy in the treatment. Moreover, the decrease in TD symptoms was significantly 
related to the decrease in total aromatic AAs $(r=0.39)$. However, these results must be taken with caution, as there were no women in the study, in whom other studies have not found similar results. ${ }^{53}$

In a similar smaller study of six children and adolescents (four males and two females, 10.5-16.5 years old), three patients under BCAA for 2 weeks showed an average decrease of $50 \%$ or more in TD movements on the SADS, and two showed an approximately $40 \%$ decrease; furthermore, when the study continued (for eligible patients), the treatment with BCAAs showed continued improvement against TD symptoms. ${ }^{54}$ BCAA use does not have significant ADRs, though weight gain may be observed. Large-scale control studies appear warranted.

\section{Drug combinations}

In a study by Kimiagar et al, ${ }^{55}$ six patients (mean age of 51.5 years) with severe buccolingual dyskinesias stopped their previous medications at the beginning of the study and took a combination of TBZ (50 mg), clonazepam (1 mg), and clozapine $(25 \mathrm{mg})$ three times a day. Within 4 weeks, all patients were free of TD symptoms. ${ }^{55}$ In practice, abrupt drug withdrawal is not recommended and drug combinations are likely to raise the ADR profile.

\section{Invasive treatments}

Surgical procedures are generally not indicated for TD unless the case is severe and all other treatment options have been exhausted.

Surgical lesions in the striatum have been noted to help some patients with TD. ${ }^{56}$ This is assumed to be due to the interruption it provides to the movement pathways, stopping/ mitigating any involuntary movements.

Deep brain stimulation (DBS) of the GPi is the preferred invasive treatment due to its reversibility and adaptability. In one study, ten selected patients with refractory neurolepticinduced TD showed an average improvement of $56 \%$ and $61 \%$ on the AIMS and ESRS scores, respectively, after 3 months of GPi stimulation, with benefits maintained at 6 months' follow-up. The experimenters discuss an improvement in patients' choreic movements within a few days. ${ }^{57}$ In a review of DBS, a collection of 17 studies (totaling 44 patients with antipsychotic-induced TD) showed an average improvement of $71.5 \%$ in AIMS scores. ${ }^{6}$

Limitations of DBS include its potential complications, such as reimplantation of leads, traction by cable(s), worsening psychiatric disorders (eg, depression), cerebral hemorrhage, and infection.

\section{Conclusion}

TD remains a prevalent and potentially irreversible motor complication of chronic DA-R blocking agents. Precautions should be undertaken to reduce risk, particularly in vulnerable populations. To date, the US Food and Drug Administration has not approved any treatment for management of TD. There are, however, several potentially beneficial treatment options available to physicians. With older TAs, the most common cause for TD, suggested first-line options include decreasing dose or switching to an ATA to benefit from their lower risk profile, though the extent of the risk reduction is debated. ${ }^{28}$ Treatment algorithms suggest the use of a combination of approaches including ATAs and/or TBZ. BCAAs may also have efficacy in TD treatment as they have shown positive results in clinical blind randomized trials. Experimental treatments such as LEV or resveratrol can also be used. Lastly, if the case of TD is intractable or unresponsive to the array of pharmaceutical interventions, DBS has shown great results in reducing TD symptoms. Concerted efforts should be invested in the fight against this "orphan disease."

\section{Acknowledgment}

The authors thank Maniza Rahman for her contribution with formatting and editing of the completed work.

\section{Disclosure}

The authors report no conflicts of interest in this work.

\section{References}

1. Paulsen JS, Heaton RK, Jeste DV. Neuropsychological impairment in tardive dyskinesia. Neuropsychology. 1994;8(2):227-241.

2. Rao AS, Camilleri M. Review article: metoclopramide and tardive dyskinesia. Aliment Pharmacol Ther. 2001;31(1):11-19.

3. Goldberg RJ. Tardive dyskinesia in elderly patients: an update. J Am Med Dir Assoc. 2002;3(3):152-161.

4. Rosenheck RA. Evaluating the cost-effectiveness of reduced tardive dyskinesia with second-generation antipsychotics. Br J Psychiatry. 2007;191:238-245.

5. Saltz BL, Robinson DG, Woerner MG. Recognizing and managing antipsychotic drug treatment side effects in the elderly. Prim Care Companion J Clin Psychiatry. 2004;6(Suppl 2):14-19.

6. Mentzel CL, Tenback DE, Tijssen MA, Visser-Vandewalle VE, van Harten PN. Efficacy and safety of deep brain stimulation in patients with medication-induced tardive dyskinesia and/or dystonia: a systematic review. J Clin Psychiatry. 2012;73(11):1434-1438.

7. Woods SW, Morgenstern H, Saksa JR, et al. Incidence of tardive dyskinesia with atypical versus conventional antipsychotic medications: a prospective cohort study. J Clin Psychiatry. 2010;71(4):463-474.

8. Lee PE, Sykora K, Gill SS, et al. Antipsychotic medications and druginduced movement disorders other than Parkinsonism: a populationbased cohort study in older adults. J Am Geriatr Soc. 2005;53(8): 1374-1379.

9. de Leon J. The effect of atypical versus typical antipsychotics on tardive dyskinesia: a naturalistic study. Eur Arch Psychiatry Clin Neurosci. 2007;257(3):169-172. 
10. Ragheb MM, Goldberg RJ. Tardive dyskinesia in geriatric patients. Aging Health. 2006;2(5):833-849.

11. Teo JT, Edwards MJ, Bhatia K. Tardive dyskinesia is caused by maladaptive synaptic plasticity: a hypothesis. Mov Disord. 2012;27(10): 1205-1215.

12. Thelma B, Srivastava V, Tiwari AK. Genetic underpinnings of tardive dyskinesia: passing the baton to pharmacogenetics. Pharmacogenomics. 2008;9(9):1285-1306.

13. Muller DJ, Chowdhury NI, Zai CC. The pharmacogenetics of antipsychotic-induced adverse events. Curr Opin Psychiatry. 2012;26(2): 144-150.

14. Seeman P. All psychotic roads lead to increased dopamine D2high receptors: a perspective. Clin Schizophr Relat Psychoses. 2008;1(4): 351-355.

15. Ito $\mathrm{H}$, Takano $\mathrm{H}$, Takahashi $\mathrm{H}$, et al. Effects of the antipsychotic risperidone on dopamine synthesis in human brain measured by positron emission tomography with L-[beta-11C]DOPA: a stabilizing effect for dopaminergic neurotransmission? J Neurosci. 2009;29(43) 13730-13734.

16. Seeman P. Targeting the dopamine D2 receptor in schizophrenia. Expert Opin Ther Targets. 2006;10(4):515-531.

17. Remington G, Kapur S. Antipsychotic dosing: how much but also how often? Schizophr Bull. 2010;36(5):900-903.

18. Ginovart N, Wilson A, Hussey D, Houle S, Kapur S. D2-receptor upregulation is dependent upon temporal course of D2-occupancy: a longitudinal [11C]-raclopride PET study in cats. Neuropsychopharmacology. 2008;34(3):662-671.

19. Stephenson CM, Bigliani V, Jones HM, et al. Striatal and extrastriatal $\mathrm{D}(2) / \mathrm{D}(3)$ dopamine receptor occupancy by quetiapine in vivo [(123)I]-epidepride single photon emission tomography (SPET) study. Br J Psychiatry. 2000;177:408-415.

20. Creed-Carson M, Oraha A, Nobrega JN. Effects of 5-HT2A and 5-HT2C receptor antagonists on acute and chronic dyskinetic effects induced by haloperidol in rats. Behav Brain Res. 2011;219(2):273-279.

21. Grimm JW, Chapman MA, Zahm DS, See RE. Decreased choline acetyltransferase immunoreactivity in discrete striatal subregions following chronic haloperidol in rats. Synapse. 2001;39(1):51-57.

22. Kelley JJ, Roberts RC. Effects of haloperidol on cholinergic striatal interneurons: relationship to oral dyskinesias. J Neural Transm. 2004;111(8):1075-1091.

23. Andreassen OA, Ferrante RJ, Aamo TO, Beal MF, Jørgensen HA. Oral dyskinesias and histopathological alterations in substantia nigra after long-term haloperidol treatment of old rats. Neuroscience. 2003;122: 717-725.

24. Pappa S, Tsouli S, Apostolou G, Mavreas V, Konitsiotis S. Effects of amantadine on tardive dyskinesia: a randomized, double-blind, placebocontrolled trial. Clin Neuropharmacol. 2010;33(6):271-275.

25. Ethier I, Kagechika H, Shudo K, Rouillard C, Lévesque D. Docosahexaenoic acid reduces haloperidol-induced dyskinesias in mice: involvement of Nur77 and retinoid receptors. Biol Psychiatry. 2004;56:522-526.

26. Mahmoudi S, Blanchet P, Levesque D. Haloperidol-induced striatal Nur77 expression in a non-human primate model of tardive dyskinesia. Eur J Neurosci. 2013;38(1):2192-2198.

27. Novak G, Gallo A, Zai CC, et al. Association of the orphan nuclear receptor NR4A1 with tardive dyskinesia. Psychiatr Genet. 2010;20(1): 39-43.

28. Margolese HC, Chouinard G, KolivakisTT, Beauclair L, Miller R, Annable L. Tardive dyskinesia in the era of typical and atypical antipsychotics. Part 2: Incidence and management strategies in patients with schizophrenia. Can J Psychiatry. 2005;50(11):703-714.

29. Busanello A, Barbosa N, Peroza L, et al. Resveratrol protects against a model of vacuous chewing movements induced by reserpine in mice. Behav Pharmocol. 2011;22(1):71-75.

30. Busanello A, Peroza L, Wagner C, et al. Resveratrol reduces vacuous chewing movements induced by acute treatment with fluphenazine. Pharmacol Biochem Behav. 2012;101(2):307-310.
31. van Harten PN, Hovestadt A. Botulinum toxin as a treatment for tardive dyskinesia. Mov Disord. 2006;21(8):1276-1277.

32. Slotema CW, van Harten PN, Bruggeman R, Hoek HW. Botulinum toxin in the treatment of orofacial tardive dyskinesia: a single blind study. Prog Neuropsychopharmacol Biol Psychiatry. 2008;32(2): 507-509.

33. Zhang WF, Tan YL, Zhang XY, Chan RC, Wu HR, Zhou DF. Extract of Ginkgo biloba treatment for tardive dyskinesia in schizophrenia: a randomized, double-blind, placebo-controlled trial. J Clin Psychiatry. 2011;72(5):615-621.

34. Howland RH. Drug therapies for tardive dyskinesia: Part 1. J Psychosoc Nurs Ment Health Serv. 2011;49(6):13-16.

35. Guay DR. Tetrabenazine, a monoamine-depleting drug used in the treatment of hyperkinetic movement disorders. Am J Geriatr Pharmacother. 2010;8(4):331-373.

36. Kenney C, Hunter C, Jankovic J. Long-term tolerability of tetrabenazine in the treatment of hyperkinetic movement disorders. Mov Disord. 2007;22(2):193-197.

37. Thaker GK, Nguyen JA, Strauss ME, Jacobson R, Kaup BA, Tamminga CA. Clonazepam treatment of tardive dyskinesia: A practical gabamimetic strategy. Am J Psychiatry. 1990;147(7):445-451.

38. Howland RH. Drug therapies for tardive dyskinesia: Part 2.J Psychosoc Nurs Ment Health Serv. 2011;49(7):17-20.

39. Littrell K, Magill A. The effect of clozapine on preexisting tardive dyskinesia. J Psychosoc Nurs Ment Health Serv. 1993;31(9):14-19.

40. Bassitt DP, Louzã Neto MR. Clozapine efficacy in tardive dyskinesia in schizophrenic patients. Eur Arch Psychiatry Clin Neurosci. 1998;248(4):209-211.

41. Louzã MR, Bassitt DP. Maintenance treatment of severe tardive dyskinesia with clozapine 5 years' follow-up. J Clin Psychopharmacol. 2005;25(2):180-182.

42. Castro F, Carrizo E, Prieto de Rincón D, et al. Effectiveness of melatonin in tardive dyskinesia. Invest Clin. 2011;52(3):252-260.

43. Shamir E, Barak Y, Plopsky I, Zisapel N, Elizur A, Weizman A. Is melatonin treatment effective for tardive dyskinesia? J Clin Psychiatry. 2000;61(6):556-558.

44. Nelson K, Mcguire J, Hausafus S. Melatonin for the treatment of tardive dyskinesia. Ann Pharmacother. 2003;37(7-8):1128-1131.

45. Lerner V, Miodownik C. Motor symptoms of schizophrenia: is tardive dyskinesia a symptom or side effect? A modern treatment. Curr Psychiatry Rep. 2011;13(4):295-304.

46. Vaddadi K, Hakansson K, Clifford J, Waddington J. Tardive dyskinesia and essential fatty acids. Int Rev Psychiatry. 2006;18(2):133-143.

47. Iwata $\mathrm{Y}$, Irie $\mathrm{S}$, Uchida $\mathrm{H}$, et al. Effects of zonisamide on tardive dyskinesia: a preliminary open-label trial. J Neurol Sci. 2012;315(1-2): 137-140.

48. Yamamura S, Ohoyama K, Nagase H, Okada M. Zonisamide enhances delta receptor-associated neurotransmitter release in striato-pallidal pathway. Neuropharmacology. 2009;57(3):322-331.

49. Lynch B, Lambeng N, Nocka K, et al. The synaptic vesicle protein SVA2 is the binding site for the antiepileptic drug levetiracetam. Proc Natl Acad Sci U S A. 2004;101(26):9861-9866.

50. Woods SW, Saksa JR, Baker CB, Cohen SJ, Tek C. Effects of levetiracetam on tardive dyskinesia: a randomized, double-blind, placebo-controlled study. J Clin Psychiatry. 2008;69(4):546-554.

51. Konitsiotis S, Pappa S, Mantas C, Mavreas V. Levetiracetam in tardive dyskinesia: an open label study. Mov Disord. 2006;21(8):1219-1221.

52. Emsley R, Turner HJ, Schronen J, Botha K, Smit R, Oosthuizen PP A single-blind, randomized trial comparing quetiapine and haloperidol in the treatment of tardive dyskinesia. J Clin Psychiatry. 2004;65(5): 696-701.

53. Richardson MA, Bevans ML, Read LL, et al. Efficacy of the branchedchain amino acids in the treatment of tardive dyskinesia in men. $\mathrm{Am}$ $J$ Psychiatry. 2003;160(6):1117-1124.

54. Richardson MA, Small AM, Read LL, Chao HM, Clelland JD. Branched chain amino acid treatment of tardive dyskinesia in children and adolescents. J Clin Psychiatry. 2004;65(1):92-96. 
55. Kimiagar I, Dobronevsky E, Prokhorov T, Miniovitz A, Rabey JM. Rapid improvement of tardive dyskinesia with tetrabenazine, clonazepam and clozapine combined: a naturalistic long-term follow-up study. J Neurol. 2012;259(4):660-664.

56. Thobois S, Poisson A, Damier P. Surgery for tardive dyskinesia. Int Rev Neurobiol. 2011;98:289-296.
57. Welter ML, Grabli D, Vidailhet M. Deep brain stimulation for hyperkinetics disorders: dystonia, tardive dyskinesia, and tics. Curr Opin Neurol. 2010;23(4):420-425.

\section{Publish your work in this journal}

Drug Design, Development and Therapy is an international, peerreviewed open-access journal that spans the spectrum of drug design and development through to clinical applications. Clinical outcomes, patient safety, and programs for the development and effective, safe, and sustained use of medicines are a feature of the journal, which has also been accepted for indexing on PubMed Central. The manuscript management system is completely online and includes a very quick and fair peer-review system, which is all easy to use. Visit http://www.dovepress.com/testimonials.php to read real quotes from published authors.

Submit your manuscript here: http://www.dovepress.com/drug-design-development-and-therapy-journal 